\title{
The Effect of Working Capital, Liquidity and Solvency on Profitability at PT Nippon Indosari Corpindo, Tbk
}

\author{
Eni Puji Astuti \\ Universitas Pamulang \\ E-mail: dosen00807@unpam.ac.id
}

\begin{abstract}
The main attraction for owners of company shareholders lies in the profitability ratio that shows the results of the management of the company's management of the funds invested. This study aims to determine: The Effect of Working Capital, Liquidity and Solvency on the Profitability of PT. Nippon Indosari Corpindo Tbk, both partially and simultaneously. Descriptive quantitative research methods, the data used are secondary data in the form of financial statements of PT. Nippon Indosari Corpindo Tbk, for a period of 9 years from 20010 - 2018 obtained through the IDX (Indonesia Stock Exchange). The analytical method used is the classic assumption test, multiple linear regression analysis, coefficient of determination and hypothesis testing. Based on the analysis results obtained the coefficient of determination (R2) of 0.928 or equal to $92.8 \%$, which means that the contribution made by working capital, liquidity and solvency to profitability reaches $92.8 .3 \%$ the remaining $7.2 \%$ is influenced by other variables which is not researched. Based on the t test partially working capital on profitability there is an effect where tcount -5.847> t table 2.575 and significance value $0.02<0.05$ and partially liquidity on profitability has no effect where tcount $1.846<\mathrm{t}$ table 2.575 and significance value $0.124>0.05$ and partially solvency to profitability there is the influence of tcount $-3.386>$ ttable 2.575 and significance value $0.02<0.05$ based on the $\mathrm{f}$ test simultaneously working capital, liquidity and solvency affect the profitability where Fcount 21.477> Ftable 5.41 with a significant value of $0.003<0.05$
\end{abstract}

Keywords: Working capital; liquidity; solvency; profitability

\section{INTRODUCTION}

Investment activities in Indonesia in recent years have tended to show an increase. This shows that companies in Indonesia are still attractive to investors. One of the main measurement tools for evaluating a company's financial performance in investment activities that are commonly used by investors is profitability ratios (Brigham \& Houston, 2013; Horne, J.C. and Wachowicz, 2007; Kasmir, 2014b; Tandelilin, 2010). The main attraction for owners of company shareholders lies in the profitability ratio that shows the results of the management of the company's management of the funds invested (Daraba et al., 2018; Mirdawati et al., 2018). The profitability ratio or profit ratio is closely related to the company's ability and the effectiveness of the company's operations in generating profits (Dowd, 1999; Sutrisno, 2013; Wong, 2006).

In managing assets, more attention is needed to manage working capital in a company to be more efficient. This is because a significant portion of assets is the proportion of working capital. Companies really need working capital to meet operational needs (Indriyani, 2017; 


\section{Jurnal Administrare: Jurnal Pemikiran Ilmiah dan Pendidikan Administrasi Perkantoran}

Vol. 7, No. 1, January - June 2020, Pages 11-20

Mulyanti, 2016; Rudianto, 2012). The readiness of a company to operate is strongly influenced by working capital. Companies that do not think of working capital well can cause losses to the company (Atmaja, 2008; Esra, 2002; Trisnawati, Rosa, \& Putri, 2013). An adequate net working capital allows a company to carry out its activities. Excessive net working capital will cause unproductive funds and will harm the company because these funds are not used effectively for operational activities. Conversely, a lack of working capital will cause a hindrance in the company's operations so that expected profits will be difficult to achieve. In addition, the company's survival is also influenced by many things, including the company's liquidity itself. Liquidity refers to the company's ability to meet its short-term obligations. The importance of liquidity can be seen by considering the impact that comes from the company's inability to meet its short-term obligations. Lack of liquidity prevents companies from making a profit. To measure the company's ability to meet its short-term obligations, a liquidity ratio is used. According to (Kasmir, 2014a) states that the liquidity ratio is a ratio that illustrates the company's ability to meet short-term obligations (debt).

This ratio is used to describe how liquid a company is and the company's ability to settle short-term liabilities using current assets. In other words, this ratio is used to measure a company's ability to pay obligations that are due soon. The importance of liquidity can be seen by considering the impact of the company's inability to meet its short-term obligations. Lack of liquidity prevents companies from profiting from discounts or opportunities for profit, it also means limiting opportunities and management actions.

In carrying out the company's operations require funding sources (Brigham \& Houston, 2007; Fahmi, 2014; Halim, 2012; Harahap, 2009). This funding source can be obtained from the company's internal and external companies. Basically the funds managed by the company must be managed properly, the proportion between sources of funds from internal companies with sources of funds from external companies must be considered because it can affect the size of profits for the company, a measurement tool to analyze the proportion between the company's internal funding sources with external funding sources can use solvency ratios. The solvency of a company shows the company's ability to meet all financial obligations if the company is currently liquidated (Riyanto, 2008). Understanding Solvency is intended as the company's ability to repay all of its debts (both short-term and long-term). Meanwhile according to (Munawir, 2010). Solvency is the company's ability to meet its financial obligations if the company is liquidated, both short-term and long-term obligations (Dewi Fitriana, 2016; Faisal, Samben, \& Pattisahusiwa, 2018; Junita \& Khairani, 2011).

\section{METHOD}

The population used by researchers in this study is the Financial Statements in the form of a Balance Sheet and Income Statement at PT. Nippon Indosari Corporindo Tbk. While the sample in this study is the Financial Statements of PT. Nippon Indosari Corporindo Tbk from 2010 to 2018 . The analytical method used in this research is to use statistical analysis through the classical assumption test approach, multiple linear regression test, coefficient of determination test, partial $t$ test and simultaneous $F$ test and then the regression results will be analyzed. 
Eni Puji Astuti; The Effect of Working Capital, Liquidity and Solvency on Profitability ...|13 
14 | Jurnal Administrare: Jurnal Pemikiran Ilmiah dan Pendidikan Administrasi Perkantoran Vol. 7, No. 1, January - June 2020, Pages 11-20

\section{RESULT AND DISCUSSION}

Profitability ratios are ratios that describe the ability of a company to make a profit through all the capabilities and available resources. In this research the writer uses Return of Asset as profitability ratio. Return of Assets is a measure of a company's ability to generate net income based on certain asset levels.

\section{Classic assumption test}

Table 1

\section{Data Normality Test}

One-Sample Kolmogorov-Smirnov Test

\begin{tabular}{lll}
\hline $\mathrm{N}$ & & Unstandardized Predicted Value \\
Normal Parameters ${ }^{\mathrm{a}, \mathrm{b}}$ & Mean & 9 \\
& Std. & .1322433 \\
& Deviation & .06301392 \\
Most Extreme Differences & Absolute & .145 \\
& Positive & .145 \\
& Negative & -.140 \\
Test Statistic & & .145 \\
Asymp. Sig. (2-tailed) & & $.200^{\mathrm{c}, \mathrm{d}}$ \\
\hline
\end{tabular}

a. Test distribution is Normal.

b. Calculated from data.

c. Lilliefors Significance Correction.

d. This is a lower bound of the true significance.

In the diatras data output, it can be seen that the normality test results show a significantly greater level than $\alpha(0.05)$, which is $0.200>0.05$, which means that the data are normally distributed. And from the curve analysis it can be seen that the data is spread around the diagram and follows the regression model so that it can be concluded that the data processed is normally distributed data so that the normality test is met.

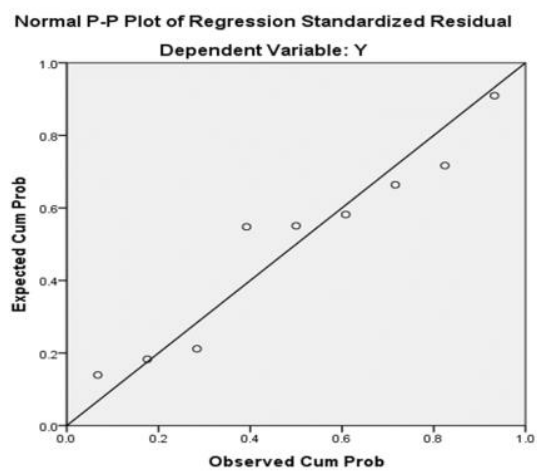

Picture 1. 
Table 2.

\section{Data Normality Test}

\section{Multicollinearity Test}

\begin{tabular}{|c|c|c|c|c|c|c|c|c|c|c|c|}
\hline \multicolumn{12}{|c|}{ Coefficients $^{a}$} \\
\hline & & \multicolumn{2}{|c|}{ Unstandardized Coefficients } & \multirow{2}{*}{$\begin{array}{c}\text { Standardized } \\
\text { Coefficients } \\
\text { Beta }\end{array}$} & \multirow[b]{2}{*}{ t } & \multirow[b]{2}{*}{ Sig. } & \multicolumn{3}{|c|}{ Correlations } & \multicolumn{2}{|c|}{ Collinearity Statistics } \\
\hline \multicolumn{2}{|c|}{ Model } & $B$ & Std. Error & & & & Zero-order & Partial & Part & Tolerance & VIF \\
\hline 1 & (Constant) & .227 & .040 & & 5.612 & .002 & & & & & \\
\hline & $\mathrm{x} 1$ & $-1.426 \mathrm{E}-7$ & .000 & -1.166 & -5.874 & .002 & -.806 & -.935 & -.705 & .365 & 2.736 \\
\hline & $\times 2$ & .028 & .015 & 377 & 1.846 & .124 & -.433 & 637 & .222 & 346 & 2.894 \\
\hline & $\times 3$ & -.206 & .061 & -.423 & -3.368 & .020 & -.357 & -.833 & -.404 & .912 & 1.097 \\
\hline
\end{tabular}

a. Dependent Variable: $Y$

From the results of the output data it is found that all VIF values $<10$ means that multicollinearity does not occur and concludes that the multicollinearity test is met.

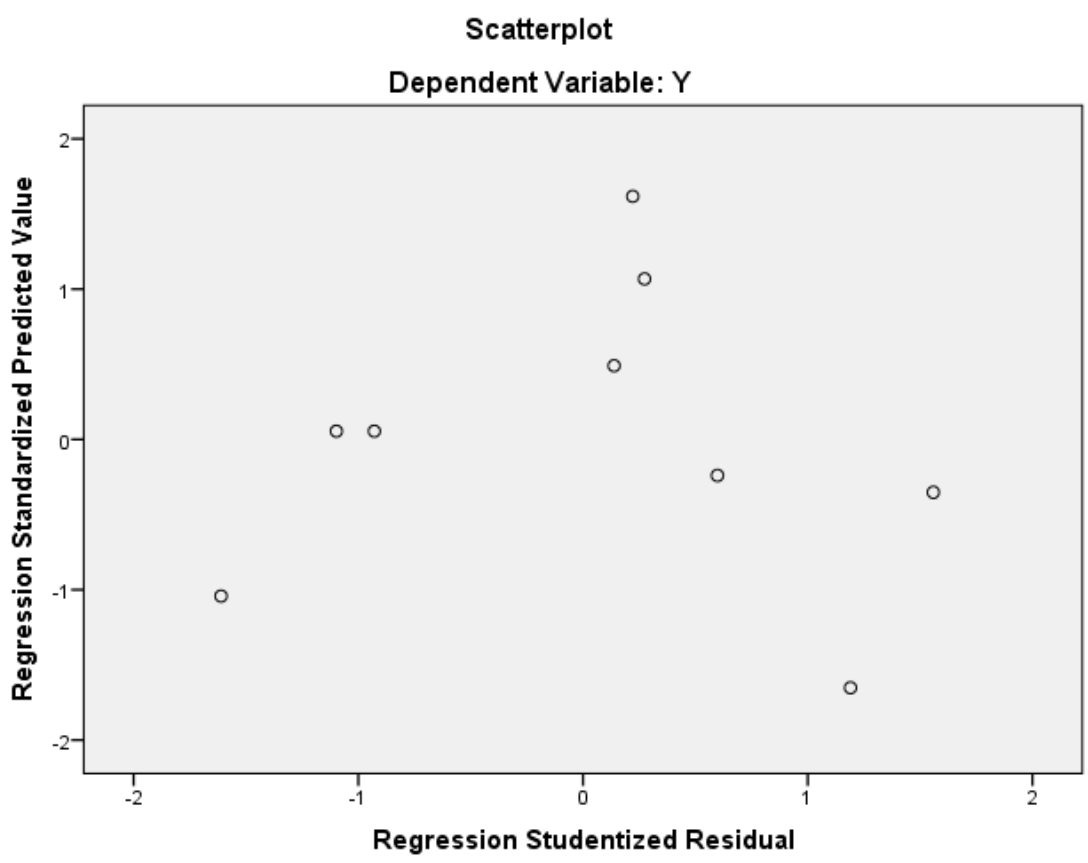

Figure 2

Heteroscedasticity Test

Figure 2 can be seen that there is no heteroscedasticity because there are no clear patterns and scatter points above and below zero on the $\mathrm{Y}$ axis so that it can be concluded that heteroscedasticity test is fulfilled. 
16 | Jurnal Administrare: Jurnal Pemikiran Ilmiah dan Pendidikan Administrasi Perkantoran Vol. 7, No. 1, January - June 2020, Pages 11-20

Table 3

Autocorrelation Test

\begin{tabular}{|c|c|c|c|c|c|c|c|c|c|c|}
\hline \multirow[b]{3}{*}{ Model } & \multirow[b]{3}{*}{$\mathrm{R}$} & \multirow[b]{3}{*}{ R Square } & \multirow[b]{3}{*}{$\begin{array}{l}\text { Adjusted R } \\
\text { Square }\end{array}$} & \multirow[b]{3}{*}{$\begin{array}{l}\text { Std. Error of } \\
\text { the Estimate }\end{array}$} & \multicolumn{6}{|c|}{ Model Summary } \\
\hline & & & & & \multicolumn{5}{|c|}{ Change Statistics } & \multirow[b]{2}{*}{$\begin{array}{l}\text { Durbin- } \\
\text { Watson }\end{array}$} \\
\hline & & & & & $\begin{array}{c}\text { R Square } \\
\text { Change }\end{array}$ & F Change & df1 & $\mathrm{df} 2$ & $\begin{array}{l}\text { Sig. F } \\
\text { Change }\end{array}$ & \\
\hline 1 & $.963^{\mathrm{a}}$ & .928 & .885 & .02220433 & .928 & 21.477 & 3 & 5 & .003 & 1.849 \\
\hline
\end{tabular}

Table 3 obtained the value of Watson durbin (DW count) of 1,849. based on criteria that have been determined DW count is between -2 and 2 ie $-2 \leq 1,849 \leq 2$ then this means there is no autocorrelation, so it can be concluded the autocorrelation test is fulfilled.

\section{Simple Linear Regression Analysis}

The equation of the multiple linear regression model can be seen in the following table 4 .

\section{Table 4}

\section{Multiple Linear Regression Analysis}

Coefficients $^{\mathrm{a}}$

\begin{tabular}{|c|c|c|c|c|c|c|c|c|c|c|c|}
\hline \multirow[b]{2}{*}{ Model } & & \multicolumn{2}{|c|}{ Unstandardized Coefficients } & \multirow{2}{*}{$\begin{array}{c}\text { Standardized } \\
\text { Coefficients }\end{array}$} & \multirow[b]{2}{*}{ t } & \multirow[b]{2}{*}{ Sig. } & \multicolumn{3}{|c|}{ Correlations } & \multicolumn{2}{|c|}{ Collinearity Statistics } \\
\hline & & $B$ & Std. Error & & & & Zero-order & Partial & Patt & Tolerance & VIF \\
\hline 1 & (Constant) & .227 & .040 & & 5.612 & .002 & & & & & \\
\hline & $X 1$ & $-1.426 \mathrm{E}-7$ & .000 & -1.166 & -5.874 & .002 & .806 & .935 & .705 & .365 & 2.736 \\
\hline & X2 & .028 & .015 & .377 & 1.846 & .124 & .433 & .637 & .222 & .346 & 2.894 \\
\hline & $\times 3$ & .206 & .061 & .423 & -3.368 & .020 & .357 & .833 & .404 & .912 & 1.097 \\
\hline
\end{tabular}

a. Dependent Variable:Y

Based on the table above, the $\mathrm{t}_{\text {-count }}$ is $-5,847$ while the table is 2,575 in the $\mathrm{t}$-distribution table. Where $t$ count $-5,847>2,575$ and the significance value of $0.02<0.05$ so that the conclusion can be drawn Ho is rejected and $\mathrm{Ha}$ is accepted so that this hypothesis states that working capital individually (partial) has a positive and significant effect on ROA.

$\mathrm{T}$ value is 1.846 while the table is 2.575 in the distribution table $\mathrm{t}$. Where $\mathrm{t}$ count $1.846<\mathrm{t}$ table 2.447 and the significance value $0.124>0.05$ so that the conclusions can be drawn HO is accepted and $\mathrm{Ha}$ is rejected so this hypothesis states that the Current Ratio individually (partial) has no positive effect and is not significant on ROA.

The $\mathrm{t}_{\text {-count }}$ is $-3,368$ while the table is 2,575 in the distribution $\mathrm{t}_{\text {-table. }}$. Where $\mathrm{t}_{\text {count }}-3,368>\mathrm{t}$ table 2.575 and significance value $0.02>0.05$ so the conclusion is $\mathrm{HO}$ is accepted and $\mathrm{Ha}$ is rejected so this hypothesis states that Debt to Total Assets individually (partial) has positive and not significant effect on ROA. 


\section{Determination Coefficient Test}

The coefficient of determination is used to determine the strength of the influence of independent variables on the dependent variable. It can be seen from the amount of the coefficient of determination (R2) that is different between zero and one. A value close to one means that the independent variables provide almost all the information needed to predict the variation of the dependent variable. From the results of data processing, the following results are obtained:

\section{Table 5}

\section{The Result of the Coefficient Analysis is Terminated}

\begin{tabular}{|c|c|c|c|c|c|c|c|c|c|c|}
\hline \multicolumn{11}{|c|}{ Model Summary ${ }^{b}$} \\
\hline \multirow[b]{2}{*}{ Model } & \multirow[b]{2}{*}{$\mathrm{R}$} & \multirow[b]{2}{*}{ R Square } & \multirow[b]{2}{*}{$\begin{array}{l}\text { Adjusted R } \\
\text { Square }\end{array}$} & \multirow[b]{2}{*}{$\begin{array}{l}\text { Std. Error of } \\
\text { the Estimate }\end{array}$} & \multicolumn{5}{|c|}{ Change Statistics } & \multirow[b]{2}{*}{$\begin{array}{l}\text { Durbin- } \\
\text { Watson }\end{array}$} \\
\hline & & & & & $\begin{array}{c}\text { R Square } \\
\text { Change }\end{array}$ & F Change & df1 & $d f 2$ & $\begin{array}{l}\text { Sig. F } \\
\text { Change }\end{array}$ & \\
\hline 1 & $.963^{\mathrm{a}}$ & .928 & .885 & .02220433 & .928 & 21.477 & 3 & 5 & .003 & 1.849 \\
\hline
\end{tabular}

The output results in table 5 show that the Deternination Coefficient (R2) is 0.926 or 92.6\% which means that ROA is influenced by the three variables of CR and DAR Working Capital. And the remaining $7.4 \%$ is influenced by other factors outside this study. This is because the indicators for evaluating the soundness of a company not only consist of the two variables $\mathrm{X}$ (working capital, current ratio and debt to total assets ratio) but there are also other indicators.

\section{F test}

F test (simultaneous test) is carried out to see together the significant influence of the independent variable on the variable.

\section{Table 6}

F test

ANOVA $^{\mathrm{a}}$

\begin{tabular}{|ll|r|r|r|r|l|}
\hline \multicolumn{1}{|l|}{} & \multicolumn{1}{|c|}{$\begin{array}{c}\text { Sum of } \\
\text { Model }\end{array}$} & Squares & df & Mean Square & $\mathrm{F}$ & \multicolumn{1}{l|}{ Sig. } \\
\hline 1 & Regression & .032 & 3 & .011 & 21.477 & $.003^{\mathrm{b}}$ \\
& Residual & .002 & 5 & .000 & & \\
& Total & .034 & 8 & & & \\
\hline
\end{tabular}

a. Dependent Variable: $Y$

b. Predictors: (Constant), X3, X1, X2

Based on the table above it can be seen that the results of the $\mathrm{F}$ Test show the $\mathrm{F}_{\text {count }}$ value of 21.477 while the $F_{\text {table }}$ of 5.41 at $(\alpha)=0.05$ and $\mathrm{dfl}=3$, df $2=9-4=5$ by looking at the 
18 | Jurnal Administrare: Jurnal Pemikiran Ilmiah dan Pendidikan Administrasi Perkantoran Vol. 7, No. 1, January - June 2020, Pages 11-20

distribution $F_{\text {table. }}$ Means the $F_{\text {value }} 21,477>F_{\text {table }} 5.41$ with a significant value of $0.003<0.05$ then $\mathrm{Ho}$ is rejected and $\mathrm{Ha}$ is accepted. This shows that there is a significant influence of Working Capital, Current Ratio (CR) and Debt to Total Assets (DAR) on Return On Assets (ROA) simultaneously (simultaneously) on the company PT. Nippon Indosari Corpindo Tbk period 2010 - 2018.

\section{CONCLUSION}

Based on the results of the study found that working capital has a positive effect on ROA. It can be seen that the $t$ value is -5.847 while the table is 2.575 in the distribution $t_{\text {table. }}$. Current ratio does not have a positive effect on ROA. It can be seen that the value of $t$ is 1.846 while the table is 2.575 in the distribution $t$ table. towards ROA. Debt to Total Assets has a positive effect on ROA. It can be seen that the $t_{\text {-count }}$ is $-3,368$ while the $t$-table is 2,575 in the distribution $t$ table. towards ROA. There is a significant influence of working capital, Current Ratio (CR) and Debt to Total Assets (DAR) on Return On Assets (ROA) together (simultaneously) at the company PT. Nippon Indosari Corpindo Tbk 2010 - 2018 period. Can be seen from the value of $F_{\text {count }}$ 21.477> F table 5.41.

\section{REFERENCES}

Atmaja, L. (2008). Teori dan Praktek Manajemen Keuangan. In Yogyakarta: ANDI.

Brigham, E. F., \& Houston, J. F. (2007). Fundamentals of financial management (Dasar-dasar Manajemen Keuangan). In Engineering and Process Economics. https://doi.org/10.1038/sj.ejhg.5200824

Brigham, E. F., \& Houston, J. F. (2013). Dasar-Dasar Manajemen Keuangan. Salemba Empat. https://doi.org/10.1145/2505515.2507827

Daraba, D., Ramli, R. M., Sakawati, H., \& Salam, R. (2018). Quality Of Service Manufacturing Of Trade License Line In Office Of Investment Investment And Licensed Agency (BPMPT) Regency Of Bulukumba.

Dewi Fitriana. (2016). Pengaruh Likuiditas, Solvabilitas,Profitabilitas, Aktivitas Dan Kebijakan Dividen Terhadap Return Saham Perusahaan Pertambangan Yang Terdaftar Pada Bei Periode 2007-2013 Dewi. Journal of Accounting.

Dowd, K. (1999). Financial Risk Management. Financial Analysts Journal. https://doi.org/10.2469/faj.v55.n4.2286

Esra, M. A. dan P. A. (2002). (2002). Manajemen Modal Kerja. Ekonomi Perusahan.

Fahmi, I. (2014). Manajemen Keuangan Perusahaan dan Pasar Modal. Manajemen Keuangan Perusahaan Dan Pasar Modal.

Faisal, A., Samben, R., \& Pattisahusiwa, S. (2018). Analisis kinerja keuangan. KINERJA. https://doi.org/10.29264/jkin.v14i1.2444 
Halim, A. (2012). Akuntansi Sektor Publik Akuntansi Keuangan Daerah. In Salemba Empat. https://doi.org/ISBN: 978-979-061-226-6

Harahap, S. S. (2009). Analisa Kritis Laporan Keuangan. In Teori Akuntansi. https://doi.org/www.rajagrafindo.com

Horne, J.C. dan Wachowicz, J. M. (2007). Prinsip-Prinsip Manajemen Keuangan. In PrinsipPrinsip Manajemen Keuangan. https://doi.org/10.4324/9781315641348

Indriyani, E. (2017). Pengaruh Ukuran Perusahaan dan Profitabilitas Terhadap Nilai Perusahaan. Akuntabilitas. https://doi.org/10.15408/akt.v10i2.4649

Junita, S., \& Khairani, S. (2011). Analisis Kinerja Perusahaan dengan Menggunakan Analisa Rasio Keuangan pada Perusahaan Telekomunikasi yang Terdaftar di Bursa Efek Indonesia. Jurusan Manajemen Fakultas Ekonomi Dan Bisnis Universitas Muhammadiyah Surakarta.

Kasmir. (2014a). Bank dan Lembaga Kuangan Lainnya. In PT. Raja Grafindo Persada jakarta.

Kasmir. (2014b). Laporan Keuangan Bank. Manajemen Perbankan.

Mirdawati, M., Jamaluddin, J., Niswaty, R., Darwis, M., \& Salam, R. (2018). The effectiveness of IMB Services at the Makassar City Investment Office and One Door Integrated Services at Makassar City. Jurnal Ilmiah Ilmu Administrasi Publik, 8(1), 37-44.

Mulyanti, D. (2016). Manajemen Keuangan Perusahaan. Jurnal Ilmiah Akuntansi.

Munawir. (2010). Analisa Laporan Keuangan Edisi 4. In Jakarta: Salemba Empat.

Riyanto. (2008). Dasar dasar pembelajaran perusahaan. In Dasar dasar pembelajaran perusahaan. https://doi.org/10.1128/MCB.4.6.1134

Rudianto. (2012). Pengantar Akuntansi Konsep \& Teknik Penyusunan Laporan Keuangan. In laporan arus kas adalah alat pembayaran yang dimiliki perusahaan dan siap digunakan untuk investasi maupun menjalankan operasi perusahaan setiap saat dibutuhkan.

Sanjaya, W. (2008). Kurikulum Dan Pembelajaran (Teori \& Praktek KTSP).

Sanjaya, W. (2010). Strategi Pembelajaran Berorientasi Standar Proses Pendidikan. System.

Sanjaya, W. (2015). Perencanaan dan Desain Sistem Pembelajaran. Kencana,Prenadamedia Group.

Sutrisno. (2013). Manajemen Keuangan Teori Konsep dan Aplikasi. In Manajemen Keuangan Teori Konsep dan Aplikasi.

Tandelilin, E. (2010). Dasar-dasar Manajemen Investasi. In Keuangan.

Trisnawati, M., Rosa, Y. Del, \& Putri, Y. E. (2013). Pengaruh Modal Kerja, Tenaga Kerja dan Jam Kerja Terhadap Pendapatan Nelayan Tradisional di Nagari Koto Taratak Kecamatan Sutera Kabupaten Pesisir Selatan. Jurnal PE STKIP PGRI Sumbar.

Uno, H. H. B. (2010). Model pembelajaran: menciptakan proses belajar mengajar yang kreatif dan efektif. In Jakarta: Bumi Aksara. https://doi.org/10.1038/cddis.2011.1 
20 Jurnal Administrare: Jurnal Pemikiran Ilmiah dan Pendidikan Administrasi Perkantoran Vol. 7, No. 1, January - June 2020, Pages 11-20

Wong, K. L. (2006). Financial management. In Professional Housing Management Practices in Hong Kong. https://doi.org/10.5005/jp/books/10677_12 